\title{
Tendencije proizvodnje kukuruza u svijetu, Hrvatskoj i Sloveniji
}

\section{Sažetak}

Uz rižu i pšenicu kukuruz je najznačajnija poljoprivredna kultura koja na svjetskoj razini osigurava trećinu energetskih potreba u stočarskoj proizvodnji. Osim u stočarstvu primjenjuje se i u ljudskoj ishrani kao i u proizvodnji različitih industrijskih proizvoda. Proteklih desetak godina odvijale su se značajne oscilacije cijena kukuruza uvjetovane ne samo njegovom proizvodnjom već i načinom korištenja. Najviše cijene kukuruza u proteklih desetak godina ostvarene su 2012. godine kada je njegova prosječna cijena bila gotovo 300 USD po toni. Unatoč projiciranom smanjenju površina pod kukuruzom do 2020. godina za $10 \%$, predviđa se 6,7\%-tno povećanje njegove proizvodnje kao posljedica rasta prinosa s danas prosječnih 5,6 t ha-1. U Hrvatskoj i Sloveniji kukuruz je, prema zasijanim površinama vodeća kultura, s prosječnim prinosima iznad svjetskog prosjeka. U analiziranom desetogodišnjem razdoblju prosječna proizvođačka cijena u Sloveniji 11 USD po toni viša je u odnosu na usporednu vrijednost u Hrvatskoj.

Ključne riječi: kukuruz, proizvodnja, Hrvatska, Svijet, trend

\section{Uvod}

Kukuruz spada među najvažnije poljoprivredne kulture današnjice po količini i po važnosti za ljude i za životinje. Kukuruz je važno krušno žito u ljudskoj prehrani, ali je još važniji kao stočna hrana te kao sirovina u mnogim industrijama, poput prehrambene, tekstilne, kemijske itd.

U stočarskoj proizvodnji troši se oko $67 \%$ svjetske proizvodnje kukuruza te se s njime podmiruje $33 \%$ energetske i čak 13\% proteinske potreba svjetske animalne proizvodnje. Najveći dio kukuruza u stočnoj hrani koristi se u svinjogojskoj te peradarskoj proizvodnji.

U novije vrijeme, kukuruz je vrlo važna kultura u proizvodnji biogoriva zbog čega su prisutne sve jače moralne dvojbe između potreba za kukuruzom kao ljudskom hranom i kukuruzom kao sirovinom u proizvodnji derivata. Razlog je dvojak. Potražnja za kukuruzom koji se troši u proizvodnji etanola izravno potiče povećanje cijene kukuruza što dovodi do porasta cijene prehrambenih proizvoda na bazi kukuruza ali i do porasta cijene stočnih proizvoda i prerađevina. Povećana potražnja za kukuruzom po nekima dovodi do „nehumanog“ korištenja ograničenih poljoprivrednih površine koje se zbog sve intenzivnije proizvodnje sve više zagađuju kao i podzemne vode.

Površine pod kukuruzom u svijetu su na razini od 182 milijuna ha uz prosječni prinos od $5,6 \mathrm{t} \mathrm{ha}^{-1}$. Ukupna svjetska proizvodnja kukuruza je oko tisuću milijuna tona, a najveći svjetski proizvođači kukuruza su SAD, Kina i Brazil s ukupno dvije trećine svjetske proizvodnje.

Cijena kukuruza na svjetskom tržištu, uz značajna godišnja kolebaju, bilježe rast. Veliki utjecaj na rast cijena imaju SAD koje kao najveći svjetski izvoznik kukuruza, sve više svoju proizvodnju kukuruza koriste za proizvodnju biogoriva, a to utječe na količine i cijene kukuruza na globalnim tržištima.

Relativno mala tržišta, poput Hrvatske i Slovenije, pod izravnim su utjecajem svjetskih trendova. Površine su relativno stabilne, a ukupna godišnja proizvodnja je više pod utjecajem klimatskih nego ekonomskih čimbenika.

Dr. sc. Magdalena Zrakić, Doc. dr. sc. Lari Hadelan, Prof. dr. sc. Ivo Grgić,

Sveučilište u Zagrebu Agronomski fakultet, Svetošimunska cesta 25, 10000 Zagreb, Hrvatska (mzrakic@agr.hr)

Doc. dr. sc. Jernej Prišenk, Univerza v Mariboru Fakulteta za kmetijstvo in biosistemske vede, Pivola 10, 2311 Hoče, Slovenia

Dr. sc. Vladimir Levak, Poljoprivredna zadruga JALŽABET, Suhodolska 21, 42203 Jalžabet, Hrvatska 
Ciljevi rada su:

prikazati promjene kod proizvodnje i cijena kukuruza na svjetskom tržištu;

prikazati osnovne pokazatelje proizvodnje kukuruza u Hrvatskoj i Sloveniji

utvrditi vezu između svjetske cijene kukuruza i svjetske cijene svinjskog mesa.

Materijali i metode

Rezultati rada temelje se na podacima referentnih statističkih baza (Državni zavod za statistiku (DZS) - Biljna proizvodnja; Eurostat; Faostat). U radu se istražuju promjene površina, proizvodnje i cijena kukuruza u svijetu, Hrvatskoj i Sloveniji te se daju projekcije do 2020. godine. U analizi statističkih podataka korištena je metoda trenda, a podaci su prikazani grafički.

\section{Rezultati i rasprava}

Uporaba kukuruza

Kukuruz (Zea mays L.) je jednogodišnja biljka porijeklom iz Srednje Amerike, točnije središnjeg Meksika. Vjeruje se da je kultivirana prije 7.000 godina od divlje trave. Uz rižu i pšenicu najznačajnija je poljoprivredna kultura u svijetu. Posebno je važna kao izvor hranjivih tvari u osiguranju sigurnosti prehrane stanovništva u manje razvijenim ekonomijama/državama (Bruinsma, 2009). Najveći dio proizvedenog kukuruza koristi se kao stočna hrana. Kod proizvodnje stočne hrane koristi se silaža cijele biljke, silaža vlažnog zrna ili klipa te suho zrno (Pospišil, 2010). Vrijedan proizvod prerade kukuruza je škrob zbog njegove široke primjene u farmaceutskoj i prehrambenoj industriji. Tekstilna industrija kukuruz koristi u proizvodnji umjetnih materijala (vlakana), a papirna industrija u proizvodnji papira.

U ljudskoj ishrani najzastupljeniji su kukuruz šećerac i kokičar. Od prerađenih oblika kukuruz se konzumira kao kukuruzna krupica (palenta) i brašno za proizvodnju kruha (u svijetu su poznate tortilje). Kukuruz sadrži oko $72 \%$ škroba, 10\% proteina i 4\% masti te kalorijsku

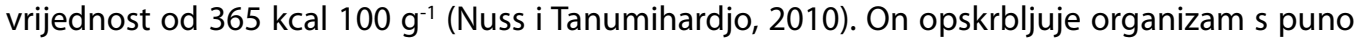
vitamina $B$ i esencijalnim mineralima zajedno s vlaknima, ali nema drugih hranjivih tvari, poput vitamina $B_{12}$ i vitamina $C$ te je općenito loš izvor kalcija, folata i željeza.

Za proizvodnju ulja se koriste kukuruzne klice. Nakon proizvodnje ulja i škroba ostaju nusproizvodi koji se koriste za hranidbu stoke. Također je i industrijska proizvodnja alkoholnih i bezalkoholnih pića nezamisliva bez kukuruza (whiskey i bourbon).

Osim navedenih načina korištenja kukuruza, u posljednjih nekoliko desetljeća on je postao cijenjena sirovina u proizvodnji biogoriva (etanola) ${ }^{1}$. Sirovinu za veći dio proizvodnje etanola čine postojeći hibridi, ali se intenzivno radi i na oplemenjivanju kako bi se kreirali novi hibridi visokog potencijala za proizvodnju biogoriva. Današnja proizvodnja etanola se još uvijek većinom temelji na preradi kukuruznog škroba iz zrna što može utjecati na povećanje cijene kukuruza (hrana za ljude i stočna hrana). Kompeticija između te dvije naizgled oprečne potrebe, može se smanjiti iskorištavanjem drugih dijelova same biljke (listovi, stabljike) koje ostaju nakon žetve. No problem kod takve proizvodnje biogoriva je da su za preradu potrebni enzimi koji celulozu pretvaraju u glukozu što poskupljuje proizvodnju etanola (Pospišil, 2010).

Trendovi proizvodnje u svijetu

Kukuruz se uzgaja diljem svijeta. U razdoblju od 2005. do 2014. godine bilježimo porast površina i proizvodnje kukuruza. U 2014. godini površine pod kukuruzom su bile oko 182 milijuna ha na kojima se proizvelo oko 1,1 tisuća milijuna tona zrna (Grafikon 1).

Modernizacijom poljoprivredne proizvodnje pa tako i proizvodnje kukuruza postignut je pozitivan trend i kod prosječnog svjetskog priroda kukuruza, koji se kretao od 4,81 t ha-1 (2005.) do 5,61 t ha-1 (2014.). 
Dok svjetska proizvodnja kukuruza ima blagi, ali neprekidan rast tijekom razdoblja, ljudska potrošnja zrna ostala je nepromijenjena. Sve više kukuruza odlazi u stočnu hranu i proizvodnju etanola, iako je kukuruz i dalje glavna hrana za većinu rastuće svjetske populacije, posebice u Africi (Ranum i sur., 2014).

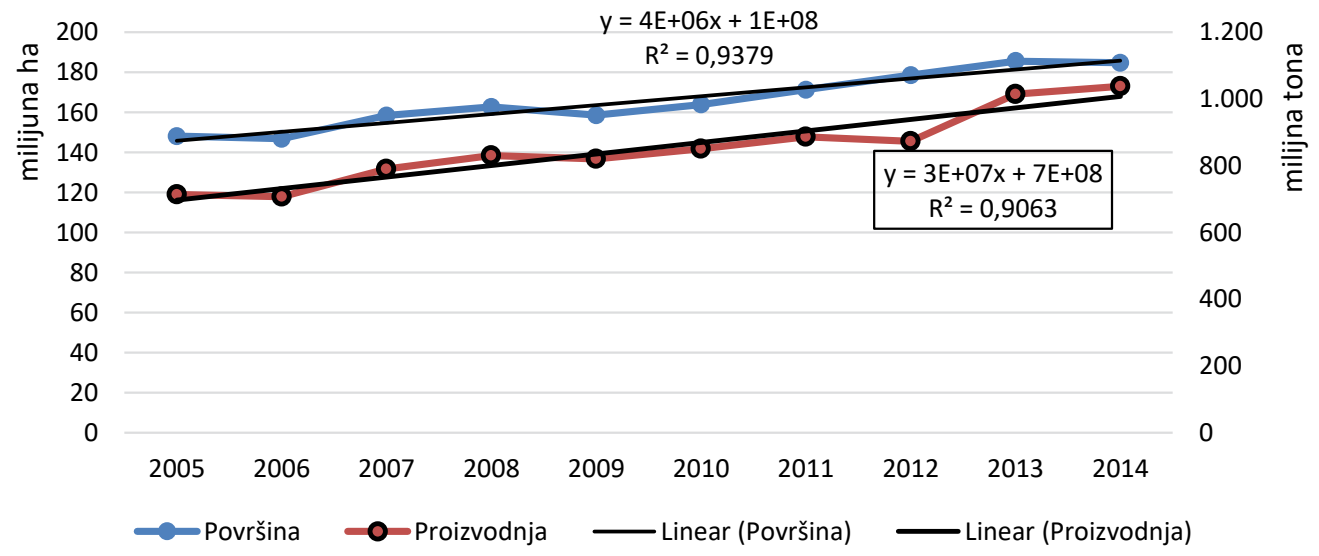

Grafikon 1: Površina i proizvodnja kukuruza u svijetu od 2005. do 2014. godine Izvor/Source: FAOstat

Projekcije pokazuju da bi do 2020. godine moglo doći do smanjenja površina pod kukuruzom na oko 164 milijuna ha uz blago povećanje proizvodnje na 1,18 tisuća milijuna tona zrna. Ovakve tendencije bi bile posljedica predviđenog porasta prosječnih priroda.

Kao bazna sirovina kukuruz se koristi u proizvodnji različitih industrijskih proizvoda, kao što su škrob, sladila, ulje, ljepilo, pića, industrijski alkohol i etanol. U posljednjih 10 godina upotreba kukuruza za proizvodnju goriva značajno se povećala (40\% proizvodnje kukuruza u SAD-u koristi se za proizvodnju etanola).

Od svjetskih regija (Grafikon 2), više od polovice svjetske proizvodnje (52\%) odvija se u Americi (Sjeverna, Srednja, Južna), zatim slijede Azija (29,6\%) i Europa (11,1\%).

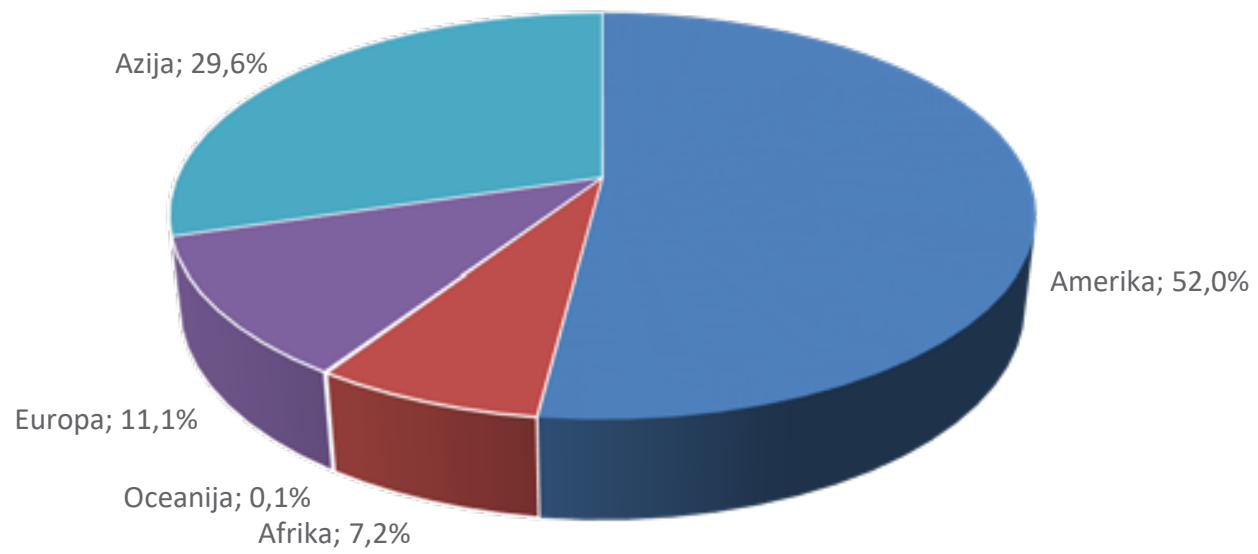

Grafikon 2: Proizvodnja kukuruza po svjetskim regijama (prosjek 2008-2014) Izvor/Source: FAOstat 
Najveći svjetski proizvođači kukuruza su SAD, Kina i Brazil (Grafikon 3). Proizvodnja se u tim trima državama kreće od 563 do 717 milijuna tona godišnje što je oko 2/3 svjetske proizvodnje.

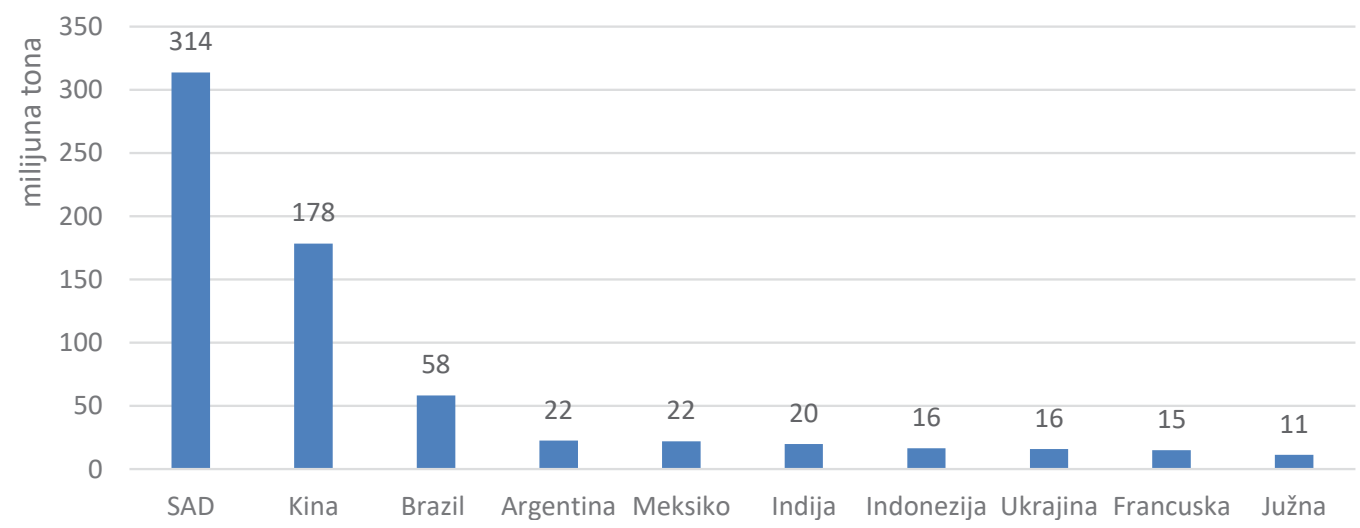

Grafikon 3: Deset najvećih svjetskih proizvođača kukuruza (prosjek 2008-2014) Izvor/Source: FAOstat (2017)

Značajniji svjetski proizvođači su i Argentina, Meksiko, Indija, Indonezija te od europskih predstavnika Francuska i Ukrajina.

Kako proizvodnja etanola troši relativno veliki udio ukupne proizvodnje kukuruza, više svjetske cijene kukuruza (Grafikon 4) pojačat će i konkurenciju na strani potražnje što može utjecati na cijenu kukuruza koji se troši u prehrani ljudi i kao stočna hrana (Ranum i sur., 2014).

$\mathrm{Na}$ Grafikonu 4 prikazan je pozitivan trend kretanja svjetske cijene kukuruza. Značajno povećanje cijena zabilježeno je u vrijeme velike gospodarske krize, tako je cijena u 2011. i 2012. godini iznosila gotovo 300 USD po toni. Od 2014. godine cijene su se ponovno vratile na razinu od prije krize.

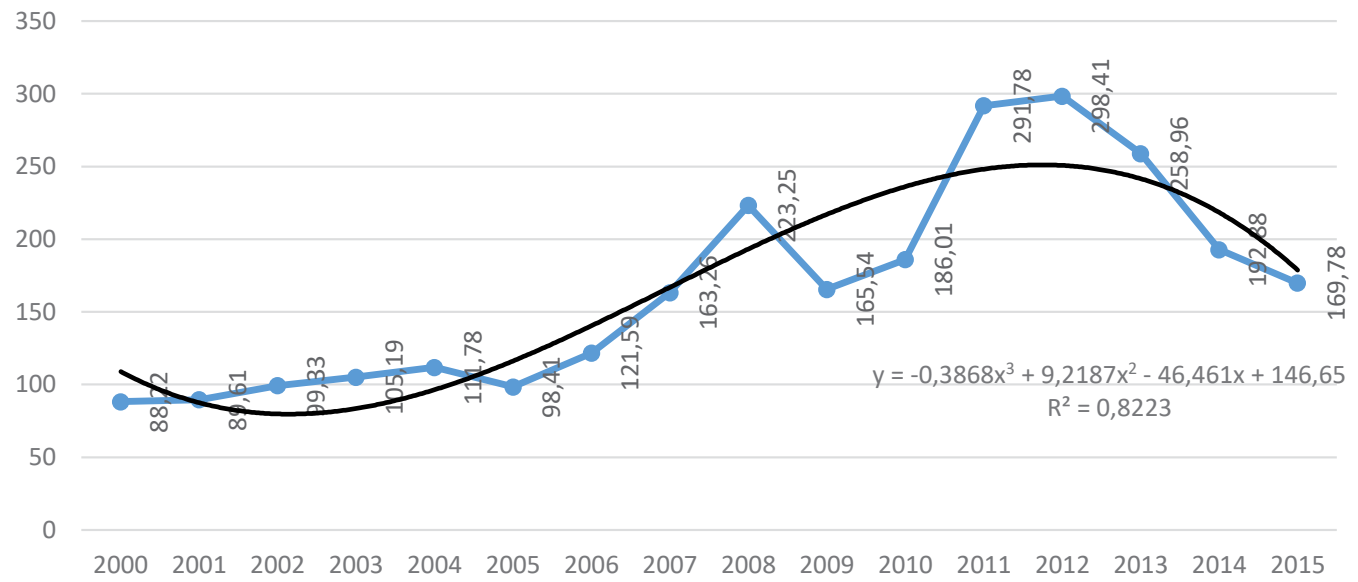

Grafikon 4: Svjetska cijena kukuruza (USD/t)

Izvor/Source: International Monetary Fund (https://fred.stlouisfed.org/series/PMAIZMTUSDM\#0) 
Procijenjeno je da će svjetska cijena kukuruza, sada ali i u budućnosti, biti u većoj mjeri posljedica načina trošenja te kulture nego li same razine proizvodnje (Radosavljević, 2007). Nestabilnosti na tržištu fosilnih goriva (nafta) i trendovi u ekologiji, na tržištu su pozicionirali pogonski etanol kao ozbiljnu opciju. U budućnosti se očekuju povećanje svjetskih površina pod kukuruzom i promjene u njegovom korištenju. Kao i kod bilo kojeg drugog usjeva, proizvodnja kukuruza je osjetljiva na klimu, a klima se mijenja u rasponima za kojima se očekuje promjena tehničke učinkovitost kukuruza (Adams i sur., 1998; FAO, 2012).

\section{Trendovi proizvodnje u Hrvatskoj i Sloveniji}

Proizvodnja kukuruza u Hrvatskoj i Sloveniji pod neposrednim je utjecajem svjetskih trendova, kako klimatskih tako i tržišnih. Prema zasijanim površinama i proizvodnji kukuruz je najvažnija poljoprivredna (ratarska) kultura u Hrvatskoj, dok u Sloveniji površine zasijane kukuruzom čine oko $40 \%$ ukupno zasijanih površina žitarica.

U Hrvatskoj se ukupno zasijane površine kreću oko 300 tisuća hektara (prosjek 2000/2016), a najveće površine zabilježene su 2005. godine (319 tisuća ha). U Sloveniji se kukuruz uzgaja na oko 40.000 ha. Na Grafikonu 5. vidljivi su vrlo slični trendovi kretanja zasijanih površina.

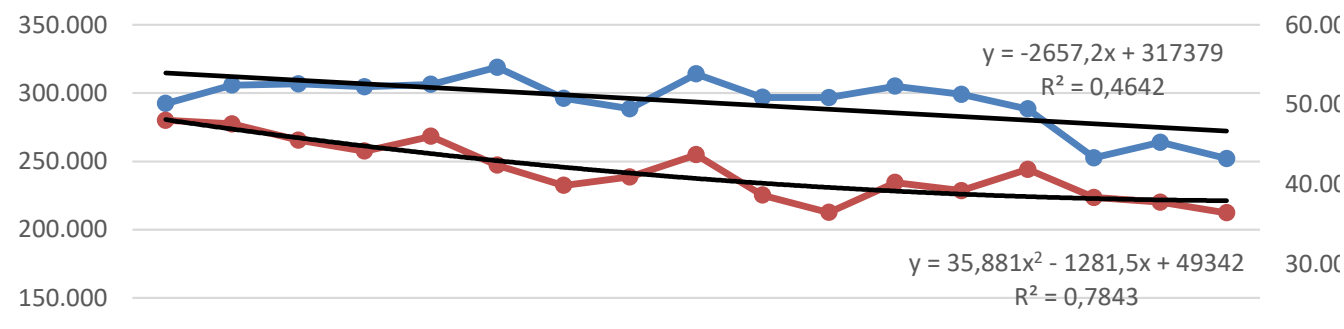

50.000

0

20002001200220032004200520062007200820092010201120122013201420152016

$\longrightarrow$ Površina/Area, HR $\longrightarrow$ Površina/Area, SI Linear (Površina/Area, HR) — Poly. (Površina/Area, SI)

Grafikon 5: Zasijane površine kukuruza u Hrvatskoj i Sloveniji, hektara Izvor/Source: DZS, Biljna proizvodnja; Eurostat

Do 2020. godine površine pod kukuruzom bi se u Hrvatskoj smanjile na oko 260 tisuće ha a u Sloveniji na oko 38 tisuća ha. Ovo bi bila posljedica smanjenja potrošnje u stočarskoj proizvodnji.

Proizvodnja kukuruza ima velika godišnja kolebanja kako u Hrvatskoj tako i u Sloveniji (Grafikon 6). Hrvatska proizvodnja se u prosjeku kretala oko 1,8 milijuna tona, a u Sloveniji oko 309.000 tona.

lako se do 2020. godine predviđa smanjenje zasijanih površina, zbog povećanja priroda očekujemo povećanje proizvodnje kukuruza u Sloveniji na oko 330 tisuća tona a u Hrvatskoj na oko 2,4 milijuna tona.

Prosječni prinos u Hrvatskoj je iznosio 6,3 $\mathrm{t} \mathrm{ha}^{-1}$, a u Sloveniji 7,5 t ha-1. lako je zabilježen negativni trend kod zasijanih površina u oba slučaja, prinosi kroz promatrano razdoblje bilježe povećanje. To ukazuje na primjenu hibrida visoke rodnosti i kvalitete zrna, modernizaciju tehnologije i tehnike proizvodnje jer primjerice prinosi u istočnoj Hrvatskoj idu i do $16 \mathrm{t} \mathrm{ha}^{-1}$ (Pospišil, 2010). 


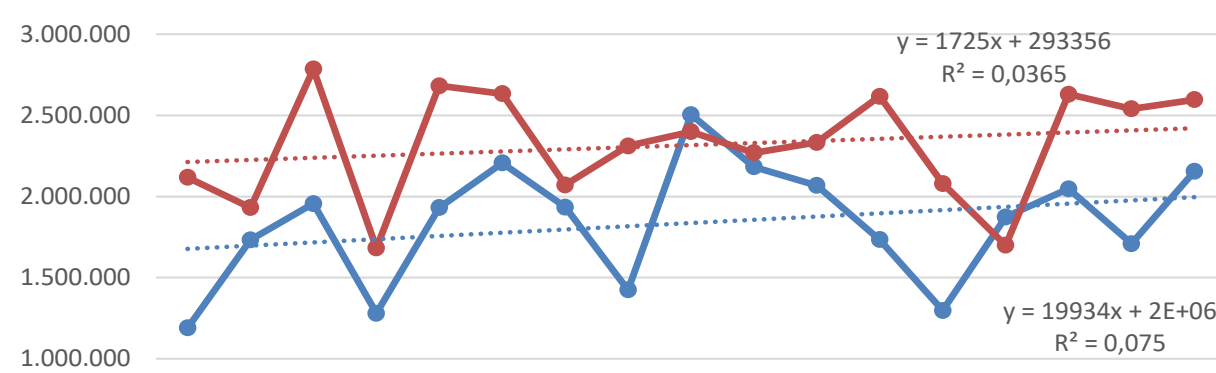

400.000

350.000

300.000

250.000

200.000

150.000

100.000

500.000

50.000

0

20002001200220032004200520062007200820092010201120122013201420152016

Proizvodnja/Production, HR

Proizvodnja/Production, SI

- Linear (Proizvodnja/Production, HR) - Linear (Proizvodnja/Production, SI)

Grafikon 6: Proizvodnja kukuruza u Hrvatskoj i Sloveniji, tona Izvor/Source: DZS, Biljna proizvodnja; Eurostat

Proizvođačka cijena kukuruza u Hrvatskoj i Sloveniji je relativno stabilna. U Hrvatskoj je u razdoblju od 2007. do 2016. godine iznosila u prosjeku 183, a u Sloveniji 194 USD po toni. Najveća cijena u Hrvatskoj bila je 2007. godine (273 USD po toni) kad je zabilježena klimatski sušna godina koja je utjecala na žetvu. U Sloveniji je najveća cijena zabilježena 2011. i iznosila je 252 USD po toni.

Od 2010. do 2012. odnosno 2013. godine zabilježen je rast cijene kukuruza na hrvatskom i slovenskom tržištu, a nakon toga dolazi do značajnog smanjenja cijena što je posljedica i smanjenja svjetskih cijena.

Obzirom da su obje države dio zajedničkog tržišta EU trendovi svjetskih kretanja proizvodnje kukuruza preko referentnih cijena u EU „se prelijevaju“ i na ova tržišta.

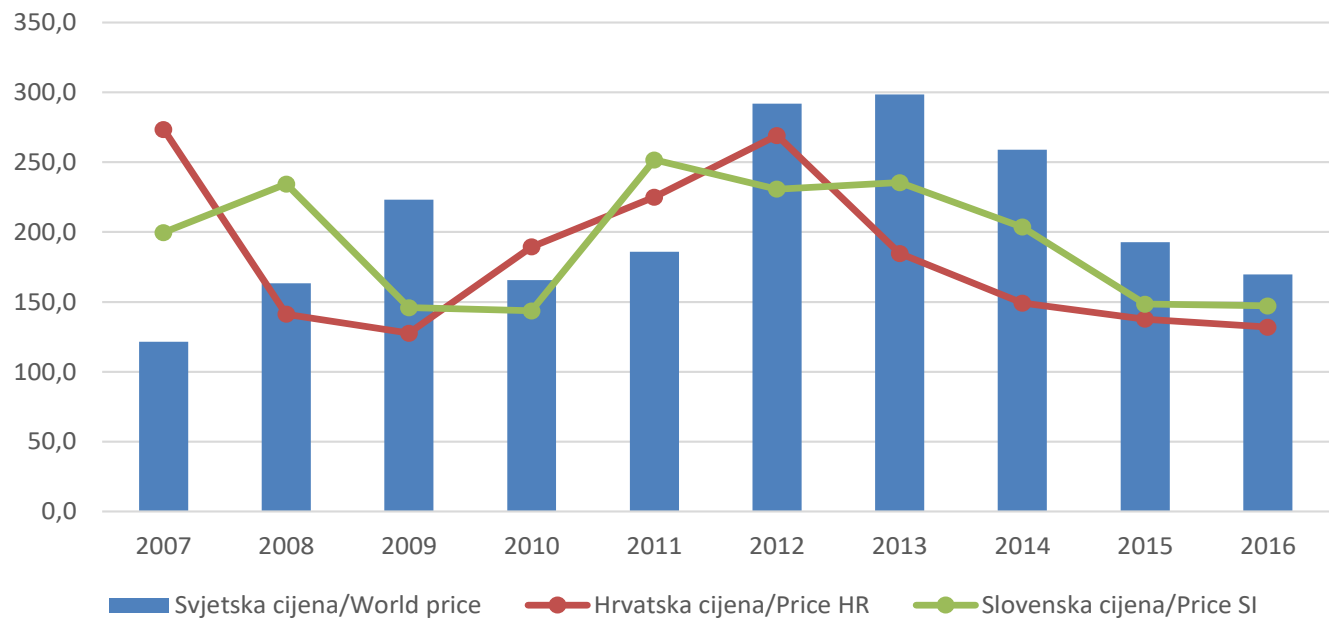

Grafikon 7: Svjetska, hrvatska i slovenska cijena kukuruza (USD/t)

Izvor/Source: International Monetary Fund; DZS, Biljna proizvodnja; Eurostat 
Kukuruz je osnovna stočna hrana za svinje, te je pretpostavka da je cijena svinjskog mesa izravno povezana s cijenom najvažnijeg inputa, tj. kukuruza.

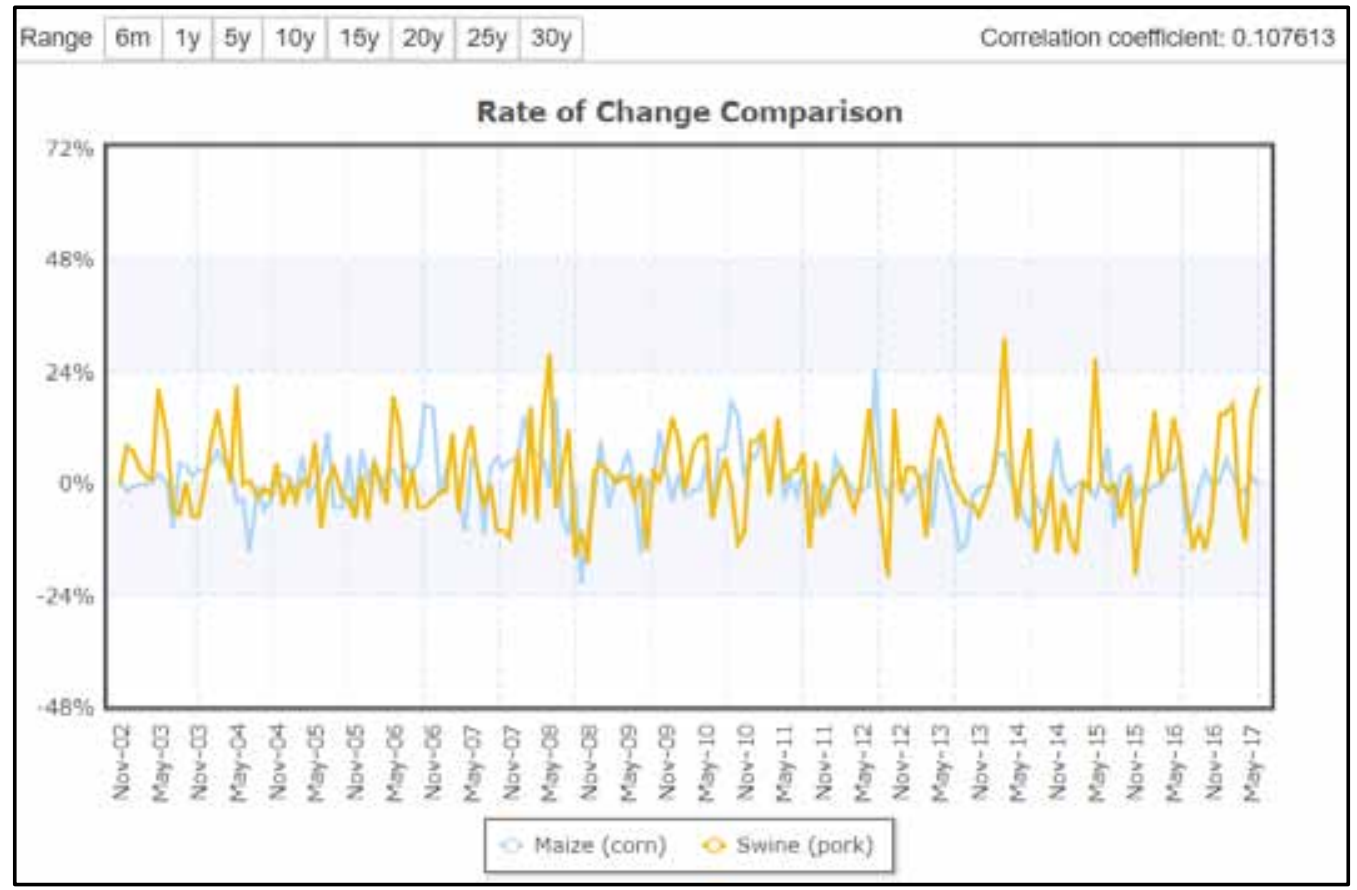

Grafikon 8: Korelacija između cijena kukuruza i cijene svinjetine na svjetskom tržištu Izvor/Source: Indeks Mundi

Ipak, prema podacima s referentnog portala Index Mundi (2017) koji prikazuje prosječne svjetske cijene svih robnih dobara, može se zaključiti da je indeks korelacije od 0,1 izračunat na temelju 15-godišnjeg prosjeka cijena kukuruza i svinjskog mesa na svjetskom tržištu, relativno mali i zanemariv.

Takav podatak upućuje na zaključak da svjetska cijena kukuruza relativno slabo utječe na formiranje svjetske cijene svinjskog mesa. To znači da na formiranje svjetske cijene svinjskog mesa utjecaj imaju neke druge nezavisne varijable (cijena drugih inputa, cijena supstituta, potrošačke navike, cijena repromaterijala, promjena proizvodne strukture i sl.)

\section{Zaključak}

Kukuruz je jedna od najznačajnijih svjetskih kultura. Osim u prehrani stanovništva, značajne količine se koriste u stočarskoj proizvodnji te u industriji za proizvodnju mnogih derivata.

lako se u razdoblju od 2005. do 2014. godine u svijetu bilježi porast površina i proizvodnje kukuruza, projekcije ukazuju da će do 2020. godine doći do smanjenja površina što zbog porasta priroda neće dovesti do smanjenja ukupne proizvodnje.

Hrvatska i Slovenija kao države sličnog povijesnog poljoprivrednog razvitka nisu po površinama niti po proizvodnji značajnije zastupljene niti u EU a još manje u svijetu. Na proizvodnju i cijene kukuruza značajan utjecaj je „prelijevanja“ sa svjetskih tržišta te također do 2020. godine očekujemo smanjenje površina pod kukuruzom uz blagi porast proizvodnje. Godišnja kolebanja cijena kukuruza u Hrvatskoj i Sloveniji prate svjetske cijene pri čemu su bile najčešće ispod svjetskih cijena. 
U analiziranom razdoblju ne postoji jača veza između svjetskih cijena kukuruza i svinjskog mesa. Promjene u potražnji za kukuruzom sve više određuje njegova potrošnja u drugim industrijama i to prvenstveno u proizvodnji etanola pri čemu odnose kod toga određuju SAD-e kao najveći proizvođač kukuruza te proizvođač i potrošač etanola.

\section{Literatura}

Adams R.M., Hurd B.H., Lenhart S., Leary N. (1998) Effects of global climate change on agriculture: an interpretative review. Climate Research, 11, 19-30.

Bruinsma J. (2009) The Resource Outlook to 2050. By How Much do Land, Water and Crop Yields Need to Increase by 2050 ? FAO Expert Meeting on How to Feed the World in 2050. FAO, Rome.

Državni zavod za statistiku (2017) Biljna proizvodnja

Eurostat (2017) Database - Agriculture: Agricultural production - Crop production

FAO (2012) FAO Statistical Year Book (2012) Europe and Central Asia. Food and Agriculture. FAO, Roma. www.FAO. org (27 January 2014).

Faostat (2017) Data - production, http://www.fao.org/faostat/en/\#data/QC (6.12.2017.)

Indeks Mundi (2017) Swine (pork) vs Maize (corn) - Price Rate of Change Comparison, http://www.indexmundi. com/commodities/?commodity=pork\&months=180\&commodity=corn (1.12.2017)

Nuss, E.T., Tanumihardjo, S.A. (2010) Maize: a paramount staple crop in the context of global nutrition. Compr. Rev. Food Sci. Food Saf. 9, 417-436.

Radosavljević, M. (2007) Kukuruz - obnovljiv izvor energije i proizvoda. PTEP, 11 (1-2), 6-8.

Pospišil, A. (2010) Ratarstvo 1. dio, Cakovec: Zrinski d.d.

Ranum, P., Peña-Rosas J.P, Garcia-Casal, M.N. (2014) Global maize production, utilization, and consumption. Ann N Y Acad Sci, 1312, 105-112. doi: 10.1111/nyas.12396.

\section{Tendencies of maize production in the world, Croatia and Slovenia}

Review paper

\section{Abstract}

Maize is the most important agricultural crop with rice and wheat that secures one third of the energy needs of livestock production worldwide. Except for cattle breeding, it is applied to human nutrition as well as to the production of various industrial products. Over the past decade, significant maize price fluctuations have occurred, not only because of its production but also on its use. The highest prices of maize over the past ten years were achieved in 2012 when its average price was almost \$300 per ton. In spite of the projected reduction in maize area by $10 \%$ in 2020, a $6.7 \%$ increase in production is expected as a result of the yield increase with today's average $5.6 \mathrm{tha}$-1. In Croatia and Slovenia maize is, according to harvested areas leading crop, with average yields above the world average. In the analyzed ten-year period, the average producer price in Slovenia is USD 11 per tonne higher than the comparative value in Croatia.

Key words: corn, production, Croatia, World, trend

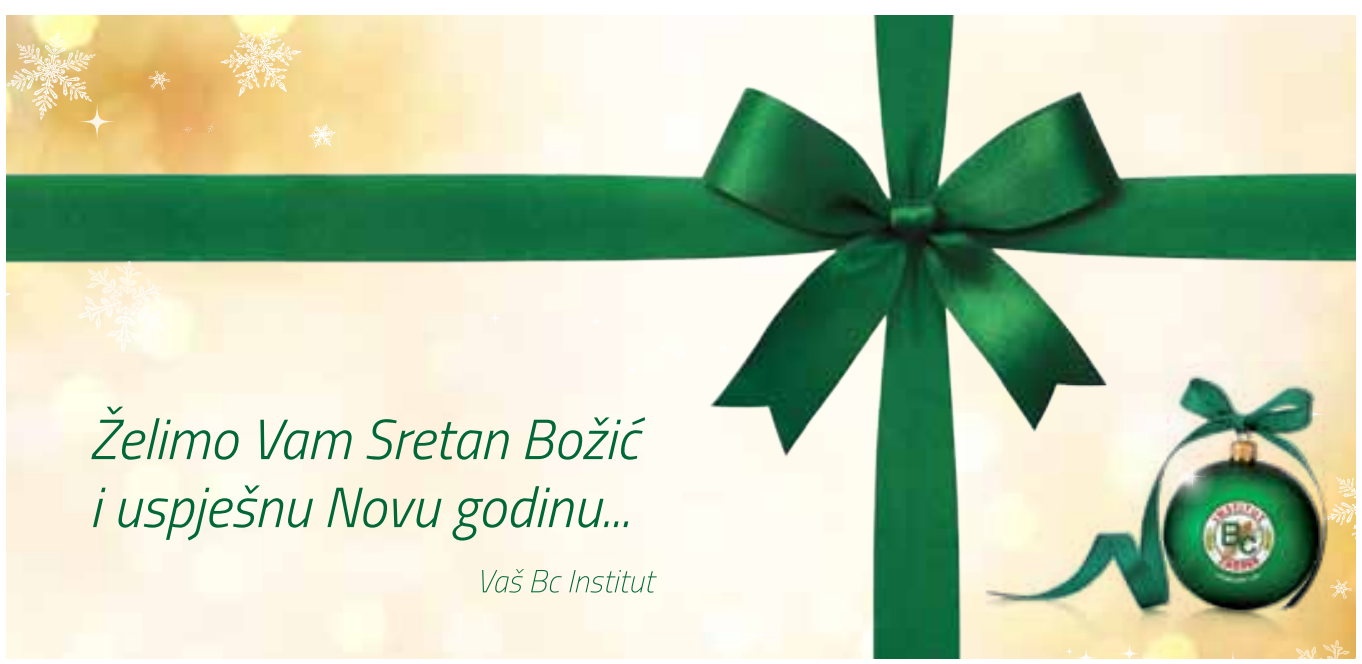

